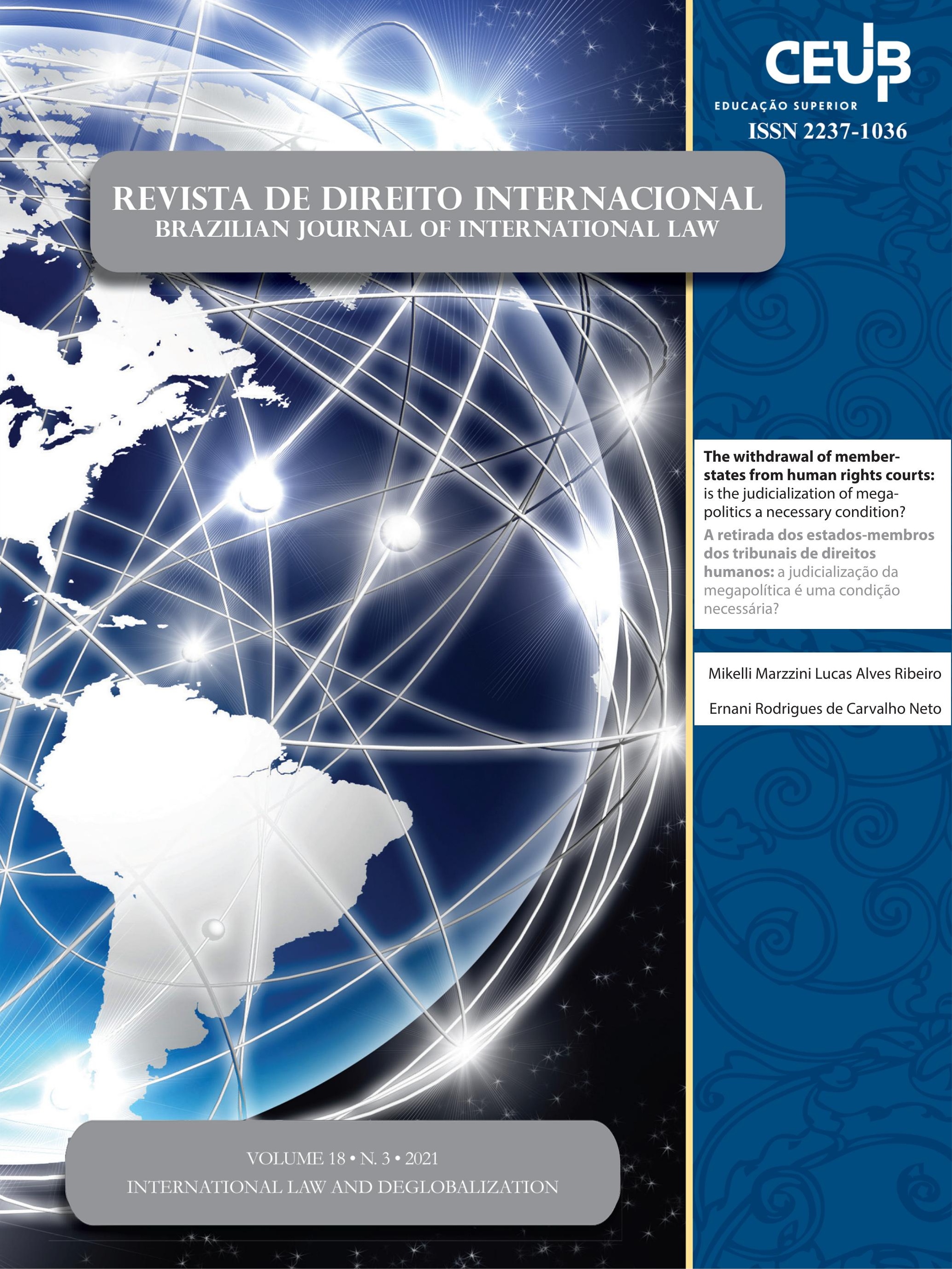




\section{Sumário}

Dossiê

EDITORIAL: INTERNATIONAL LAW AND DE-GLOBALIZATION 16 Ivette Esis, Jaime Tijmes e Juan Enrique Serrano

El régimen jurídico de la Inversión Extranjera Directa: ¿De la limitación a la desGLOBALIZACIÓN?

Ivette Esis Villarroel e Yoselyn Bermúdez Abreu

Desglobalização, Brexit e os novos acordos entre Reino Unido e União Europeia .34 Angela Limongi Alvarenga Alves e Daniel Freire e Almeida

FisCALIDAD Y DESGLOBALIZACIÓN EN UN MUNDO CRECIENTEMENTE UNILATERAL Julio César Muñiz Pérez

Covid, Covax e o Refluxo da Governança Global Salem Hikmat Nasser e Luiza Nogueira Papy

The International Monetary Fund and COVID-19: Old and New Challenges of a Post-World War II INTERNATIONAL INSTITUTION

Virdzhiniya Petrova Georgieva

Artigos Sobre outros temas

RULE OF LAW IN THE INTERNATIONAL ARENA: THE IMPORTANCE OF PRACTICES OF LEGALITY . 112 Angela Jank Calixto

THE WITHDRAWAL OF MEMBER-STATES FROM HUMAN RIGHTS COURTS: IS THE JUDICIALIZATION OF MEGA-POLITICS A NECESSARY CONDITION?. 132

Mikelli Marzzini Lucas Alves Ribeiro e Ernani Rodrigues de Carvalho Neto 
Princípio da precaução e mudança climática: uma análise do Acordo de Paris e das Conferências das Partes.

Jamille Bergamaschine Mata Diz e Carolina Mendonça de Siqueira

A INTERAÇÃo ENTRE OS ESPAÇOS CONSTITUCIONAIS NACIONAIS E INTERNACIONAIS E SEUS IMPACTOS NO SISTEMA DE FONTES DO DIREITO: AS LIÇÕES DA PROTEÇÃO COOPERATIVA DE DIREITOS HUMANOS E O CASO DA INTEGRAÇÃO EUROPEIA ...................................................... 173

Diego Fernandes Guimarães

WTO’s Engagement with National Law: Three Illustrations from India 193 Ravindra Pratap

GESTÃo MIGRATÓRIA E INTEGRAÇÃo REGIONAL: UMA ANÁLISE SOBRE A REGULAMENTAÇÃo NORmativa dos fluxos migratórios irregulares na União Europeia À luz do Novo Pacto Europeu sobre Migração e Asilo.................................................................. 212 João Mauricio Malta Cavalcante Filho e Eugênia Cristina Nilsen Ribeiro Barza

The African Regional Human and Peoples' Rights System: 40 years of progress and CHALLENGES. 232 Juan Bautista Cartes Rodríguez

The USMCA Sunset Clause 258 Jaime Tijmes-Ihl e Yvonne Georgina Tovar Silva

REFLEXÕES SOBRE A UNIVERSALIDADE DO DIREITO INTERNACIONAL DOS DIREITOS HUMANOS A RESPEITO DA PROTEÇÃO ÀS MULHERES 273 Érica Rios de Carvalho

A CRItical legal anAlysis OF GENDER EQUALITY IN INTERNATIONAL TRADE AgREEMENTS...287 Parul Shukla e Sheikh Sultan Aadil Huque

FEMinicídio, FEMicídio E Ódio NA AGENDA: o ASSASSinAto DAS MUlHERES NA AmÉriCA LATINA...... 309 Vinícius Ferreira Baptista

LEGAL IDEOLOGY IN THE CONTEXT OF DEVELOPMENT OF THE LEGAL STATE AND FORMATION OF THE CIVIL SOCIETY IN UKRAINE 
Direito INTERNACIONAL PÚBLICO NO ENTREgUERRAS (1919-39): A INSTITUCIONALIZAÇÃO DOS PROJETOS JURÍDICOS DE PAZ E MANEJO DOS POVOS NÃO SOBERANOS.

Hugo Luís Pena Ferreira

O Caso Gomes Lund (“Guerrilha Do Araguaia”) dez anos depois: Desafios para o cumPRIMENTO INTEGRAL PELO ESTADO BRASILEIRO

João Gabriel Archegas, Felipe Klein Gussoli e Vivian Cristina Lima López Valle

DiÁlogos museológicos: o Regime jurídico brasileiro e o Código de Ética do ConseLHo InTERnacional de Museus.

Paula Gonçalves do Carmo, Emerson Gabardo e Daniel Wunder Hachem 


\title{
The withdrawal of member-states from human rights courts: is the judicialization of mega-politics a necessary condition?*
}

\author{
A retirada dos estados-membros \\ dos tribunais de direitos humanos: a \\ judicialização da megapolítica é uma condição \\ necessária?
}

\author{
Mikelli Marzzini Lucas Alves Ribeiro** \\ Ernani Rodrigues de Carvalho Neto***
}

\begin{abstract}
Currently, there are about 24 functioning international courts. Within the interdisciplinary field of International Law and International Relations, a new agenda has focused in evaluating the process of the States' resistance to adhere to decisions by those international institutions. A specific way to resist is the withdrawal by States that are party to regional human rights courts (RHRC). This paper is particularly interested in investigating this phenomenon. Based on the ideas of Ran Hirschl, the work aims to evaluate if the judicialization of mega-politics issues by these courts can be considered a necessary condition for the withdrawal of Member States. The article uses methodological strategies present in the set-theory literature, as well as congruence analysis in its evaluation process. The study maps cases of withdrawal and threats to withdraw the three regional human rights courts in existence, with the central idea to verify if decisions on issues of megapolitics were present were those actions occurred. To supplement this, it also sought to identify whether the decisions from the courts were linked to the justifications for withdrawal or threat to withdraw by the States. The preliminary results show that the judicialization of mega-politics was indeed present when States exit or threaten to exit from RHRC, suggesting that rulings about mega-politics are a necessary (albeit not sufficient) condition for the outcome evaluated to occur.
\end{abstract}

* Recebido em 16/04/2021

Aprovado em 10/08/2021

** Professor Adjunto de Relações Internacionais do Departamento de Ciência Política da Universidade Federal de Pernambuco, atuando na graduação e na pós-graduação em Ciência Política (PPGCP-UFPE)

Email: mikelli.lucas@ufpe.br

*** Doctor of Politic Scienceaat the University of São Paulo. Associate Professor, Political Science Department. Dean of Master in Public Policy (MPPP-UFPE).

E-mail: ernanicarvalho@gmail.com
Keywords: Judicialization of mega-politics; Regional Human Rights Courts; Backlash. Withdrawal.

\section{Resumo}

Atualmente, existem cerca de 24 tribunais internacionais em funcionamento. No campo interdisciplinar do Direito Internacional e das Relações Internacionais, uma nova agenda tem se concentrado em avaliar o processo de resistência dos Estados em aderir às decisões dessas instituições internacionais. Uma forma específica de resistir é a retirada por parte dos Estados que 
fazem parte dos tribunais regionais de direitos humanos (RHRC). Este artigo está particularmente interessado em investigar esse fenômeno. Com base nas ideias de Ran Hirschl, o trabalho visa avaliar se a judicialização de questões megapolíticas por esses tribunais pode ser considerada uma condição necessária para a retirada dos Estados membros. O artigo utiliza estratégias metodológicas presentes na literatura da teoria dos conjuntos, bem como a análise de congruência em seu processo de avaliação. $\mathrm{O}$ estudo mapeia casos de retirada e ameaças de retirada dos três tribunais regionais de direitos humanos existentes, com a ideia central de verificar se as decisões sobre questões de megapolítica estavam presentes quando essas ações ocorreram. Para complementar, também procurou identificar se as decisões dos tribunais estavam vinculadas às justificativas de retirada ou ameaça de retirada por parte dos Estados. Os resultados preliminares mostram que a judicialização da megapolítica esteve de fato presente quando os Estados saem ou ameaçam sair do RHRC, sugerindo que as decisões sobre a megapolítica são uma condição necessária (embora não suficiente) para que o desfecho avaliado ocorra.

Palavras-chave: Judicialização da megapolítica; Tribunais Regionais de Direitos Humanos; Folga. Cancelamento.

\section{Introduction}

With the end of the Cold War and the rise of the United States as a single superpower, there was an increase in international institutionalism. Under this new period, academics saw a consolidated liberal international order: the end of history ${ }^{1}$. This can be seen, for example, with the unlocking of the Security Council ${ }^{2}$, the emergence of international institutions focused on liberalizing economic relations among states - such as the World Trade Organization ${ }^{3}$ - and several other international legal structures aimed at solving different

${ }^{1}$ FUKUYAMA, Francis. O fim da História e o último homem. Rio de Janeiro: Rocco, 1992.

2 GLANVILLE, Luke. Sovereignty and the responsibility to protect: a new history. Chicago: The University of Chicago Press, 2014.

3 In which later on incorporated States outside the western liberal axis, such as China, became members. global problems, such as the ones derived from specific thematic international treaties ${ }^{4}$.

Particularly in the field of human rights, the process of institutional expansion during the $20^{\text {th }}$ century was very significant. States used their sovereignty to create formal international institutions that would restrict their very sovereignty ${ }^{5}$. From a period that started timidly, with just one political Declaration (therefore, non-binding) -the Universal Declaration of Human Rights (1948) - began the creation of a large number of international treaties and institutions, whether they were intergovernmental, non-judicial, or even adjudicatory bodies, such as international courts ${ }^{6}$.

With this process of international institutionalization, States started to grant individuals - their own citizens - the capacity to question domestic institutions before international organizations. Sometimes, the decisions from international bodies on internal matters have, indeed, a binding effect, as in the case of the aforementioned international courts.

The history of international liberal institutionalism, despite progressive, was not free from challenges. The bipolar conflict was an example of that. More recently, despite the intensification of the globalization process, the emergence of domestic factors has raised questions regarding the capacity of these institutions. Specifically regarding human rights institutions, some cases are paradigmatic, such as the notorious contestation of the UN Human Rights Council's authority. Marked even by the withdrawal of the United States, following the Trump's administration more general external policy trends - which are now being reversed by the Biden administration?

This paper seeks to analyze this type of resistance/ attack to a particular group of international judicial institutions: regional human rights courts (RHRC), taking into account that these courts tend to judicialize topics

\footnotetext{
${ }^{4}$ HURRELL, Andrew. On Global Order: power, values and constitution of international order. New York: Oxford, 2007.

${ }^{5}$ FORSYTHE, David. Human Rights in International Relations. 2. ed. Cambridge: Cambridge University Press, 2006.

${ }^{6}$ DONNELLY, Jack. The Social Construction of International Human Rights. In: DUNNE, Tim; WHEELER, Nicholas J. Human Rights in Global Politics. Cambridge: Cambridge University Press, 1999.

7 Available at: https://www.cfr.org/in-brief/bidens-first-foreignpolicy-move-reentering-international-agreements, acesso em: Feb. 01, 2021.
} 
that are politically sensitive for the States ${ }^{8}$. More specifically, it aims to analyze the main issues associated with withdrawal by States that have effectively left RHRCs or that have threatened to do so. This paper analyzes this behavior with regards to three existing regional courts (the Inter-American Court of Human Rights, the European Court of Human Rights, and the African Court on Human and Peoples' Rights).

In a broader sense, the analysis in this paper departs from the idea that domestic societal preferences have an effect on States' external positioning - which the International Relations literature usually classifies as new liberalism?. More specifically, however, the theoretical perspective that directs this research is oriented towards applying the concept of judicialization of mega-politics developed by Ran Hirschl, in issues involving human rights international courts.

Generally speaking, issues of mega-politics are about matters of great political relevance which often cause division and define a State. "These range from electoral outcomes and corroboration of regime change to matters of war and peace, foundational collective identity questions, and nation-building processes pertaining to the very nature and definition of the body politic" ${ }^{10}$. From this concept, we seek to answer the following question: are rulings on mega-politics issues a necessary condition for there to be State resistance to RHRCs? Thus, it is evaluated whether the judicialization of mega-politics was present or not in the central cases that gave rise to a withdrawal or threat to withdraw.

Methodologically, the paper combines a set-theory approach ${ }^{11}$ with congruence analysis for case compa-

\footnotetext{
8 SOLEY, Ximena; STEININGER, Silvia.Parting ways or lashing back? Withdrawals, backlash and the Inter-American Court of Human Right. International Journal of Law in Context, v. 14, n. 2, p. 237-257, 2018; VOETEN, Erik. Populism and Backlashes against International Courts. Perspectives on Politics, p. 01-16, 2019; MADSEN, Mikael Rask; CEUBLAK, Pola; WEIBUSCH, Micha. Backlash against International Courts: Explaining Resistance to International Courts. International Journal of Law in Context, v. 14, n. SI2, p. $197-$ 220, 2018.

9 MORAVCSIK, Andrew. Taking Preferences Seriously: A liberal theory of international politics. International Organization, v. 51, n. 4, p. 513-553, 1997.

${ }^{10}$ HIRSCHL, Ran. The Judicialization of Mega-Politics and the Rise of Political Courts. Annual Review of Political Science, v. 11, n. 1, p. 93-118, 2008.

11 SCHNEIDER, Carsten; WAGEMANN, Claudius. Set-Theoretic Methods for the Social Sciences: A Guide to Qualitative Comparative Analysis (Strategies for Social Inquiry). Cambridge: Cambridge University Press, 2012.
}

rison ${ }^{12}$. The sources to find justifications are extracted from official positions and, especially, from a systematic review of the literature that analyzed the cases. It mainly makes use of research done by other works, which elaborated a similar systematization of this literature, and are then used as a guide ${ }^{13}$.

This work intends to contribute to a broader analysis regarding international courts and the problem of the judicialization of politics in these institutions. It also seeks to contribute to the literature centered on empirical studies in International Law and the interdisciplinarity of International Law and Political Science/International Relations ${ }^{14}$, as can be seen in the next section.

\section{The Judicialization of Politics and International Relations}

Since the early 2000s, specialized literature has brought International Law again to the center of discussions in Political Science and International Relations. It is understood that this is a growing phenomenon that was spurred by academic debates regarding international regimes back in the $1980 \mathrm{~s}^{15}$. In the beginning of the $21^{\text {st }}$ century, authors begin to talk about the idea of legalization of international politics ${ }^{16}$. More recently, the issue is branched out into a discussion on the judicialization of international relations ${ }^{17}$ or the judicialization of domestic politics in international courts ${ }^{18}$.

12 GEORGE, Alexander; BENNETT', Andrew. Case Studies and Theory Development in the Social Science. Cambridge, Massachusetts: MIT Press, 2005.

13 SOLEY, Ximena; STEININGER, Silvia. Parting ways or lashing back? Withdrawals, backlash and the Inter-American Court of Human Right. International Journal of Law in Context, v. 14, n. 2, p. 237-257, 2018; VOETEN, Erik. Populism and Backlashes against International Courts. Perspectives on Politics, p. 01-16, 2019.

${ }^{14}$ A preliminary version of this research was presented at the $12^{\text {th }}$ Conference of the Brazilian Political Science Associated, between 19 and 23 October 2020.

15 KRASNER, Stephen D. Structural causes and regime consequences: regimes as intervening variables. International Organization, v. 36, n. 2, p. 185-205, Spring, 1982.

16 ABBOTT, Kenneth et al. "The concept of legalization". International Organization, v. 54, n. 3, p. 401-419, 2000.

17 ALTER, Karen J; HAFNER-BURTON, Emilie Marie; HELFER, Laurence. Theorizing the Judicialization of International Relations. International Studies Quarterly, v. 63, n. 3, p. 449-463, 2019.

18 RIBEIRO, Mikelli; RAMANZINI, Isabela; SANTOS, Alana. A Corte Interamericana De Direitos Humanos E a judicialização Internacional Da política doméstica. Meridiano 47 - Journal of Global Studies, v. 21 Jul. 2020. 
The judicialization of politics, which starts recently to be a part of international relations, has been identified for some time in domestic politics dynamics ${ }^{19}$. The idea of constitutional supremacy, which came into force in the majority of countries, especially after the fall of authoritarian governments in East Europe, Latin America, Asia, and Africa, enabled the appearance and/ or strengthening of constitutional courts. These began to rule on sensitive matters in the law and public policies of governments, acting in certain situations as veto players in institutional changes at the national level.

Despite all of this breadth,

the political science literature addressing the judicialization of politics worldwide remains surprisingly sketchy. The term judicialization suffers from analytical fuzziness; it is often used in an umbrella-like fashion to refer to different, if often inter-related, processes $^{20}$.

At the international level, judicialization - when it is present - threatens to lessen the sovereignty of States and autonomy of governments. The nature and extent of judicial involvement in international politics grew quite significantly in the post-Cold War period. This is understood to be derived from the appearance of new characteristics, among them the increase in numbers of international courts and subsequent activation of old and new courts and other adjudicatory bodies by interested actors, as well as the expansion of the right of non-state actors to make demands on States in these external jurisdictions ${ }^{21}$.

Although there is some diversity in non-judicial adjudicatory bodies that influence international politics, such as arbitration courts and organs created by international treaties (such as the Human Rights Committee), the roughly 24 international courts currently functioning are the most evident legal institutions. This type of judicialization is the most salient in the situations in which courts decide beyond specific measures for a case, seeking to impose measures of non-repetition ${ }^{22}$.

\footnotetext{
19 HIRSCHL, Ran. The Judicialization of Politics. Oxford Handbook of Political Science. Oxford: Oxford University Press, 2011. p. 93118.

${ }^{20}$ HIRSCHL, Ran. The Judicialization of Mega-Politics and the Rise of Political Courts. Annual Review of Political Science, v. 11, n. 1, p. 93-118, 2008.

${ }^{21}$ ALTER, Karen J; HAFNER-BURTON, Emilie Marie; HELFER, Laurence. Theorizing the Judicialization of International Relations. International Studies Quarterly, v. 63, n. 3, p. 449-463, 2019.

22 HILLEBRECHT, Courtney. Domestic Politics and International Human Rights Tribunals: the problem of compliance. Cambridge: Cambridge
}

At times, decisions by international courts require measures such as changes in the legislation by the States' parliaments and the creation of specific public policies to be implemented by the Executive ${ }^{23}$. Because of these patterns of interference, judicialization of politics at the external arena may lead to resistance and processes of reversal of the institutionalization level.

The States' resistance processes under the decisions of international adjudicatory organs may be restricted to a specific ruling (pushbacks), or indeed more intense, even threatening the institutions themselves, being classified as backlash: constant and systematic processes of critique against the institution, as well as grave patterns of non-compliance regarding its decisions ${ }^{24}$.

In the domestic arena, resistance to unwanted decisions from constitutional courts are usually made with initiatives by the Executives or parliaments, whereupon, through bills or constitutional alterations, similar to overturning a ruling ${ }^{25}$. In the international context, one of the possible political responses to negative decisions from international courts is rejecting their jurisdiction.

Resistance to international courts is particularly noted in the case of regional human rights courts (RHRC), given the political sensitivity of the themes dealt with. Often, these oppositions lead States to leave the organ whether as a deliberate action to undermine it or just as a means to void its effects on domestic politics.

The justifications to leave a human rights court - or threats to do so - are varied. They can be based on the social issue involving the theme being dealt with by a certain decision (e.g., abortion, immigration, death penalty), or even an emphatic defense of state sovereignty (when there is the perception that the demand being

University Press, 2014.

${ }^{23}$ RIBEIRO, Mikelli; RAMANZINI, Isabela; SANTOS, Alana. A Corte Interamericana De Direitos Humanos E a judicialização Internacional Da política doméstica. Meridiano 47 - Journal of Global Studies, v. 21, Jul. 2020.

${ }^{24}$ SOLEY, Ximena; STEININGER, Silvia.Parting ways or lashing back? Withdrawals, backlash and the Inter-American Court of $\mathrm{Hu}-$ man Right. International Journal of Law in Context, v. 14, n. 2, p. $237-$ 257, 2018.

${ }^{25}$ HIRSCHL, Ran. The Judicialization of Mega-Politics and the Rise of Political Courts. Annual Review of Political Science, v. 11, p. 93-118, 2008; HIRSCHL, Ran. The Judicialization of Politics. Oxford Handbook of Political Science. Oxford: Oxford University Press, 2011. p. 93-118. 
made by a court is an interference in domestic politics) 26.

This leads to the following question: is there a necessary condition that must be present for a State to leave an international human rights court? Our argument is that decisions conflicting with the conception of mega-politics - established by Ran Hirsch ${ }^{27}$ as the topics of the highest political significance which usually define and divide societies - would be that condition. That is, some decisions by these courts affect too strongly issues within the States' political and social context ${ }^{28}$.

This is a new research agenda. While authors have been trying for some time to explain why States create International Human Rights Courts ${ }^{29}$, specifically for this paper the investigation is centered around when they resist these institutions to the point of leaving them. From the point of view of an international relations approach, this paper brings to the fore the role of domestic actors' preferences in the actions of States within international institutions, a research agenda identified within the new liberalism approaches ${ }^{30}$.

\section{The resistance of states to international human rights courts: an effect of the judicialization of mega-politics?}

In his article on the judicialization of mega-politics, Ran Hirsch ${ }^{31}$ differentiates it from what he classifies

${ }^{26}$ SOLEY, Ximena; STEININGER, Silvia.Parting ways or lashing back? Withdrawals, backlash and the Inter-American Court of Human Right. International Journal of Law in Context, v. 14, n. 2, p. 237-257, 2018; VOETEN, Erik. Populism and Backlashes against International Courts. Perspectives on Politics, p. 01-16, 2019.

${ }^{27}$ HIRSCHL, Ran. The Judicialization of Mega-Politics and the Rise of Political Courts. Annual Review of Political Science, v. 11, p. 93-118, 2008.

${ }^{28}$ MADSEN, Mikael Rask; CEUBLAK, Pola; WEIBUSCH, Micha. Backlash against International Courts: Explaining Resistance to International Courts. International Journal of Law in Context, v. 14, n. SI2, p. 197-220, 2018.

${ }^{29}$ MORAVCSIK, Andrew. "The Origins of Human Rights Regimes: Democratic delegation in Postwar Europe". International Organization, v. 54, n.2, p. 217-252, 2000.

${ }^{30}$ MORAVCSIK, Andrew. Taking Preferences Seriously: A liberal theory of international politics. International Organization, v. 51, n. 4, p. 513-553, 1997.

31 HIRSCHL, Ran. The Judicialization of Mega-Politics and the Rise of Political Courts. Annual Review of Political Science, v. 11, p. 93-118, 2008. as judicialization of ordinary, daily politics. The author identifies three levels of judicialization. In the first, are matters of due process, criminal issues, and of civil rights and liberties; at the second level is the process of reviewing acts by the public administration, being included here, via the courts, several specific public policies; at the third level of judicialization, mega-politics is found.

For this differentiation, Hirschl states that it is required to have a clear understanding of what politics is. Given that there is a grey zone regarding what are purely political matters and political issues that are under the purview of the judiciary branch, there is some difficulty in mapping the unwanted interference of the judiciary in the political dynamic via judicialization. Hirschl ${ }^{32}$ highlights that a country's social context becomes a relevant element to identify controversial issues as one theme may be taboo for one a given society (such as quota policies or abortion) and not to another. Evaluating this contextual difference becomes crucial to understand when the judicialization of mega-politics occurs.

Hirsch $^{33}$ uses examples to demonstrate which topics are of highest political significance. There are several illustrations that the author presents, issues that go from national security, foreign policy, macroeconomic policy, to decisions on election results, or even socially divisive issues, such as immigration in certain western countries. To name a few, some key examples in the text are several decisions by countries' supreme courts, such as one that discusses the definition of Israel as a Jewish and democratic State, the role of religion in Turkey and India, matters involving the use of torture against terrorists in Israel, the status of the French language in Canada, the disqualification and barring of politicians' candidacies, transitional justice in Latin America, among others ${ }^{34}$. Overall, rulings on issues of mega-politics in the States involve the participation of national courts in political issues with a high degree of

\footnotetext{
32 HIRSCHL, Ran. The Judicialization of Mega-Politics and the Rise of Political Courts. Annual Review of Political Science, v. 11, p. 93-118, 2008.

33 HIRSCHL, Ran. The Judicialization of Mega-Politics and the Rise of Political Courts. Annual Review of Political Science, v. 11, p. 93-118, 2008.

${ }^{34}$ HIRSCHL, Ran. The Judicialization of Mega-Politics and the Rise of Political Courts. Annual Review of Political Science, v. 11, p. 93-118, 2008.
} 
social divisiveness - or what the author refers to as "watershed political issues" 35 .

From this list given by Hirschl, the first step in this research was to try and systematically organize the ideas, creating deductive categories. Consequently, the list below shows seven categories, six of which were theory-driven. The seventh comes from combining the definition of judicialization of mega-politics and the topics found in the analyses of the cases; therefore, a categorization that combines deductive and inductive (data-driven) inferences.

That was the way found to guide the analyses. Of course, there are limitations to it. Possible cases that would fit into the author's understanding of mega-politics may have been left out; in addition, there is always some level of subjectivity to this kind of procedure, which can lead to some randomness in the elaboration of the categories. These are difficulties and limitations of qualitative research of this kind. What was relevant was operationalizing the theory in some way that allowed for case comparison in order to verify if the conditions and results vary as expected ${ }^{36}$.

Table 1: Analytical categories

\begin{tabular}{|l|l|}
\hline Categories & Judicialized issues \\
of the Executive & $\begin{array}{l}\text { These are issues involving } \\
\text { national security policies, } \\
\text { such as decisions on matters } \\
\text { regarding terrorism; foreign } \\
\text { policy, such as deployment } \\
\text { of troops overseas, decisions } \\
\text { on the legality of separatist } \\
\text { movements; or social and } \\
\text { economic policies, such as } \\
\text { universal healthcare systems, } \\
\text { fiscal austerity policies, } \\
\text { among others. }\end{array}$ \\
\hline
\end{tabular}

\begin{tabular}{|c|c|}
\hline Categories & Judicialized issues \\
\hline $\begin{array}{l}\text { Political-electoral } \\
\text { processes }\end{array}$ & $\begin{array}{l}\text { Cases in which courts are } \\
\text { called upon to decide on the } \\
\text { legality of candidacies and } \\
\text { political parties, conduction } \\
\text { of elections and results, pos- } \\
\text { sible voters, impeachment } \\
\text { of leaders in office, issues } \\
\text { involving leaders of the op- } \\
\text { position, among other issues } \\
\text { connected to electoral dyna- } \\
\text { mics. }\end{array}$ \\
\hline $\begin{array}{l}\text { Change in regime and } \\
\text { national construction }\end{array}$ & $\begin{array}{l}\text { Decisions on the legality of } \\
\text { new constitutions, restaura- } \\
\text { tion of democratic regimes, } \\
\text { and crucial modifications to } \\
\text { current regimes (often invol- } \\
\text { ving coups d'état). } \\
\end{array}$ \\
\hline $\begin{array}{l}\text { Transitional and re- } \\
\text { staurative justice }\end{array}$ & $\begin{array}{l}\text { Cases that discuss the inve- } \\
\text { stigation, trial, punishment, } \\
\text { and reparation in situations } \\
\text { involving authoritarian re- } \\
\text { gimes. Often deals with the } \\
\text { establishment of truth com- } \\
\text { missions and other processes } \\
\text { involving memory. }\end{array}$ \\
\hline National identity & $\begin{array}{l}\text { Considered one of the most } \\
\text { clear-cut cases of this type of } \\
\text { judicialization by the author. } \\
\text { These are situations that } \\
\text { involve, for example, the official } \\
\text { languages and religions in the } \\
\text { State. }\end{array}$ \\
\hline Socially divisive themes & $\begin{array}{l}\text { Normally deals with rights and } \\
\text { public policies that divide/ } \\
\text { polarize society in a given State. } \\
\text { Examples of this are issues like } \\
\text { abortion and gun control in the } \\
\text { United States }{ }^{37} \text {. }\end{array}$ \\
\hline
\end{tabular}

\footnotetext{
37 Observation: This is a broader category and thus harder to separate between ordinary and extraordinary judicialization. A more detailed look is required on the sociopolitical context of the country under analysis.
}

\footnotetext{
35 HIRSCHL, Ran. The Judicialization of Mega-Politics and the Rise of Political Courts. Annual Review of Political Science, v. 11, p. 93-118, 2008.

${ }^{36}$ GEORGE, Alexander; BENNETT, Andrew. Case Studies and Theory Development in the Social Science. Cambridge, Massachusetts: MIT Press, 2005.
} 


\begin{tabular}{|l|l|}
\hline Categories & Judicialized issues \\
\hline $\begin{array}{l}\text { Measures critical to the } \\
\text { regime }\end{array}$ & $\begin{array}{l}\text { Decisions that confront the } \\
\text { authority of the political } \\
\text { regime in question, occasionally } \\
\text { reversing anti-democratic } \\
\text { actions by non-democratic } \\
\text { regimes. Normally they are } \\
\text { labelled by governments as } \\
\text { external interference, threat to } \\
\text { sovereignty, foreign imperialism, } \\
\text { among others }{ }^{38} .\end{array}$ \\
\hline
\end{tabular}

Source: elaborated based on Hirschl ${ }^{39}$.

To find the cases where States left or threatened to leave the respective regional courts, as well as cases associated with these results, a targeted literature review was conducted and supplemented with materials extracted from $i^{40}$. From this review, combined with the case analysis, we arrived at a preliminary list presented in the table below.

Table 2: Cases analyzed

\begin{tabular}{|l|l|l|l|}
\hline States & Court & $\begin{array}{l}\text { Result of } \\
\text { Threat }\end{array}$ & $\begin{array}{l}\text { Presence } \\
\text { of rulings } \\
\text { on mega- } \\
\text { Politics }\end{array}$ \\
\hline Benin & CADHP & $\begin{array}{l}\text { Partial } \\
\text { Withdrawal }\end{array}$ & Yes \\
\hline
\end{tabular}

38 Observation: this is a category that was created from a combination between the concept (theory-driven) and the finds (data-driven).

39 HIRSCHL, Ran. The Judicialization of Mega-Politics and the Rise of Political Courts. Annual Review of Political Science, v. 11, p. 93-118, 2008; HIRSCHL, Ran. The Judicialization of Politics. Oxford Handbook of Political Science. Oxford: Oxford University Press, 2011. p. 93-118.

${ }^{40}$ Among the literature used in the review, we highlight the following: SOLEY, Ximena; STEININGER, Silvia.Parting ways or lashing back? Withdrawals, backlash and the Inter-American Court of $\mathrm{Hu}-$ man Right. International Journal of Law in Context, v. 14, n. 2, p. $237-$ 257, 2018; VOETEN, Erik. Populism and Backlashes against International Courts. Perspectives on Politics, p. 01-16, 2019; CONTESSE, Jorge. "Resisting the Inter-American Human Rights System". Yale J. Int'l L., v. 44, n. 2, p. 180-232, 2019; ADJOLOHOUN, Segnonna. A crisis of design and judicial practice? Curbing state disengagement from the African Court on Human and Peoples' Rights. African Human Rights Law Journal, v. 20, n.1, p. 1-40, 2020; MADSEN, Mikael Rask. From Boom to Backlash? The European Court of Human Rights and the Transformation of Europe. In: AUST, H.; ESRA, D. (ed.). The European Court of Human Rights: Current Challenges in Historical and Comparative Perspective. Edward Elgar Publishing, 2021; MADSEN, Mikael Rask; CEUBLAK, Pola; WEIBUSCH, Micha. Backlash against International Courts: Explaining Resistance to International Courts. International Journal of Law in Context, v. 14, n. SI2, p. 197-220, 2018.

\begin{tabular}{|l|l|l|l|}
\hline States & Court & $\begin{array}{l}\text { Result of } \\
\text { Threat }\end{array}$ & $\begin{array}{l}\text { Presence } \\
\text { of rulings } \\
\text { on mega- } \\
\text { Politics }\end{array}$ \\
\hline Ivory Coast & CADHP & $\begin{array}{l}\text { Partial } \\
\text { Withdrawal }\end{array}$ & Yes \\
\hline Rwanda & CADHP & $\begin{array}{l}\text { Partial } \\
\text { Withdrawal }\end{array}$ & Yes \\
\hline Tanzania & CADHP & $\begin{array}{l}\text { Partial } \\
\text { Withdrawal }\end{array}$ & Yes \\
\hline Greece & CEDH & $\begin{array}{l}\text { Formal } \\
\text { Withdra- } \\
\text { wal* }\end{array}$ & Yes \\
\hline $\begin{array}{l}\text { United } \\
\text { Kingdom }\end{array}$ & CEDH & $\begin{array}{l}\text { Domestic } \\
\text { Reform }\end{array}$ & Yes \\
\hline Russia & CEDH & $\begin{array}{l}\text { Domestic } \\
\text { Reform }\end{array}$ & Yes \\
\hline Peru & CIDH & $\begin{array}{l}\text { Partial } \\
\text { Withdra- } \\
\text { wal* }\end{array}$ & Yes \\
\hline $\begin{array}{l}\text { Dominican } \\
\text { Republic }\end{array}$ & CIDH & $\begin{array}{l}\text { Partial } \\
\text { Withdrawal }\end{array}$ & Yes \\
\hline $\begin{array}{l}\text { Trinidad } \\
\text { and Toba- } \\
\text { go }\end{array}$ & CIDH & $\begin{array}{l}\text { Formal } \\
\text { Withdrawal }\end{array}$ & Yes \\
\hline $\begin{array}{l}\text { Venezuela } \\
\text { Withdrawal }\end{array}$ & CIDH & Yes \\
\hline
\end{tabular}

Source: the authors.

*States that withdrew and later returned.

\section{Description and brief analysis of the cases}

In this section, we briefly describe the relevant cases ruled by the respective courts, in order to present why they are considered (when they happened) situations where judicialization of mega-politics was present. The division is done based on each regional human rights system, observing the effects in each regional court.

\subsection{Inter-American Court of Human Rights}

Beginning with the Inter-American Court of $\mathrm{Hu}$ man Rights (IACHR), four situations were found of direct resistance from States where exit from the organ 
was used as a strategy - be it total (formal) or partial (indirect or informal). Among them, there were two formal withdrawals, Trinidad and Tobago and Venezuela, as well as two in which the withdrawal from the court's jurisdiction was done indirectly (partial withdrawal) Peru and Dominican Republic - with one of them reversed afterwards (Peru). Within the idea of backlash, the literature also points to other relevant situations, such as Bolivia and Ecuador ${ }^{41}$, however, since there was no explicit strategy of threat to withdraw or effective withdrawal in those cases, we chose to exclude them from the analysis.

It is understood here that a formal withdrawal occurs when the country denounces the international treaty that binds it to a particular court - it is worth remembering that denunciation of an international treaty is the institution established by International Law for a State to formally withdraw itself from a court. When there were situations where, in practice, there was a withdrawal, although without formalization, it was considered a partial withdrawal, according to the current literature ${ }^{42}$. In all cases, these correlated with rulings that involve mega-politics issues ${ }^{43}$.

The case that triggered the withdrawal in the Inter-American system was Trinidad and Tobago's. It was the first country to denounce the American Human Rights Convention. Trinidad and Tobago's action was associated with a particular theme: the disputes involving this Caribbean country and the respective Court regarding the death penalty. Although the American Human Rights Convention does not forbid the death penalty, the Court touches on the topic as it interrelates to other rights, especially when discussing long waits by inmates on death row. According to the current literature, several cases regarding this issue led the country to withdraw from the American Convention in $1999^{44}$.

Trinidad and Tobago have a large criminality problem and the death penalty is seen as an adequate policy

\footnotetext{
${ }^{41}$ VOETEN, Erik. Populism and Backlashes against International Courts. Perspectives on Politics, p. 01-16, 2019.

${ }^{42}$ CONTESSE, Jorge. "Resisting the Inter-American Human Rights System”. Yale J. Int'l L., v. 44, n. 2, p. 180-232, 2019.

${ }^{43}$ Given that the idea of the paper is to evaluation condition, the language of causality is avoided.

${ }_{44}$ SOLEY, Ximena; STEININGER, Silvia.Parting ways or lashing back? Withdrawals, backlash and the Inter-American Court of Human Right. International Journal of Law in Context, v. 14, n. 2, p. 237-257, 2018; CONTESSE, Jorge. "Resisting the Inter-American Human Rights System”. Yale J. Int'l L., v. 44, n. 2, p. 180-232, 2019.
}

to deal with this matter by the country's authorities and society. According to Jorge Contesse ${ }^{45}$, both public opinion and the national elite strongly support the death penalty in the country. Thus, that issue can be inserted in the mega-politics category of "socially divisive themes". When justifying denouncing the Convention, the country's ambassador stated that the Court became an instrument for those who want to abolish the death penalty in the State ${ }^{46}$, a declaration that can be seen as an indication that the issue is too sensitive for the society.

The second country to withdraw was Peru. Unlike the previous case, this is a withdrawal that is classified as partial, since there was no formal denunciation of the American Human Rights Convention. The first issue associated with Peru's withdrawal was an internal decision against Chilean nationals, who were accused of treason and terrorism. The Inter-American Court understood that there was violation of the due process and ordered a new trial. In addition to this, there were two others awaiting judgments: one on the removal of judges from the country's Constitutional Court, and other on stripping the nationality of a media owner that was critical of the government ${ }^{47}$.

All of these occurrences refer to decisions that resulted from Fujimori's authoritarian regime. They were decisions of high "political significance" 48 to the regime. The challenge was understanding them from some of the categories extracted from Hirschl's ${ }^{49}$ texts. The difficulty lies in the author having sought to reflect on issues of mega-politics from constitutional (therefore, national) issues in democratic countries. Aforementio-

${ }^{45}$ CONTESSE, Jorge. "Resisting the Inter-American Human Rights System”. Yale J. Int'l L., v. 44, n. 2, p. 180-232, 2019.

${ }^{46}$ SOLEY, Ximena; STEININGER, Silvia.Parting ways or lashing back? Withdrawals, backlash and the Inter-American Court of $\mathrm{Hu}-$ man Right. International Journal of Law in Context, v. 14, n. 2, p. $237-$ 257, 2018.

${ }^{47}$ SOLEY, Ximena; STEININGER, Silvia.Parting ways or lashing back? Withdrawals, backlash and the Inter-American Court of Human Right. International Journal of Law in Context, v. 14, n. 2, p. $237-$ 257, 2018.

48 In addition to the definition already presented on mega-politics, the author also characterizes it as being: "core political controversies that define the boundaries of the collective or cut through the heart of entire nations". HIRSCHL, Ran. The Judicialization of MegaPolitics and the Rise of Political Courts. Annual Review of Political Science, v. 11, p. 93-118, 2008.

${ }^{49}$ HIRSCHL, Ran. The Judicialization of Mega-Politics and the Rise of Political Courts. Annual Review of Political Science, v. 11, p. 93-118, 2008; HIRSCHL, Ran. The Judicialization of Politics. Oxford Handbook of Political Science. Oxford: Oxford University Press, 2011. p. 93-118. 
ned case, in addition to the institutions analyzed here being international courts, there was also the context of an autocratic regime. As the literature states, resistance in Peru was directly related to the country being ruled by an autocratic regime ${ }^{50}$.

Thus, we sought to create, from conceptual inference, a new category that refers to cases of regime contestation. Therefore, it is directed towards judgments by international human rights courts regarding "measures critical to the regime" - Table 1, category 7 . For lack of better terminology, that was the label adopted for the category, created from the cases (data-driven). It was a combination of rulings on sensitive issues to regime with issues that are the prerogative of the Executive (category 1), such as terrorism.

As a result from its opposition, Peru tried to exit only from the Inter-American Court although without withdrawing from the Convention. However, the Commission and the Court denied that possibility ${ }^{51}$. In practice, Peru stopped abiding by the Court, but without formally withdrawing from the American Human Rights Convention via a denunciation ${ }^{52}$. After the fall of Fujimori, with the advocacy of important civil society sectors and government actors, Peru was reintegrated in the Inter-American system ${ }^{53}$.

Similar to the Peruvian case, Venezuelan case was also classified as a sensitive matter for the political regime. In this case, however, there was a formal withdrawal. Before denouncing the American Convention, Hugo Chávez' government had steadily escalated its critique of international institutions, not only regional ones $^{54}$. As the literature points out ${ }^{55}$, the justification

${ }^{50}$ CONTESSE, Jorge. "Resisting the Inter-American Human Rights System”. Yale J. Int'l L., v. 44, n. 2, p. 180-232, 2019.

51 Case of the Constitutional Court v. Peru. Available at: https://www. corteidh.or.cr/docs/casos/articulos/seriec_55_ing.pdf, acesso em: Jan. 5, 2021.

52 CONTESSE, Jorge. "Resisting the Inter-American Human Rights System”. Yale J. Int'l L., v. 44, n. 2, p. 180-232, 2019.

53 BERNARDI, Bruno Boti. O sistema interamericano de direitos humanos e a justiça de transição no Peru. Revista de Sociologia e Politica, v. 23, n. 54, p. 43-68, 2015.

${ }^{54}$ CONTESSE, Jorge. "Resisting the Inter-American Human Rights System”. Yale J. Int'l L., v. 44, n. 2, p. 180-232, 2019.

55 VOETEN, Erik. Populism and Backlashes against International Courts. Perspectives on Politics, p. 01-16, 2019; SOLEY, Ximena; STEININGER, Silvia.Parting ways or lashing back? Withdrawals, backlash and the Inter-American Court of Human Right. International Journal of Law in Context, v. 14, n. 2, p. 237-257, 2018; CONTESSE, Jorge. "Resisting the Inter-American Human Rights System”. Yale J. Int'l L., v. 44, n. 2, p. 180-232, 2019. used for the withdrawal was that the Court (as well as other organs in the region) served only as an instrument of United States imperialism.

Several rulings by the Inter-American court were criticized by the Venezuelan government; the last one that preceded the denunciation (in 2011) was on the political participation of the opposition leader Leopoldo Lopez, which could have possibly led to framing it under the "political-electoral processes" category. However, when observing the description of events, it is clear that there is a resistance to the organ itself, which occurs due to the perception that the Court not only condemned Venezuela in specific cases, but attacked the regime itself. In this sense, the most salient category is still "measures critical to the regime".

The last situation in which a ruling on mega-politics was identified dealt with an issue involving the Dominican Republic. The issue on which the Dominican government's resistance was based on a more specific matter: the concession of nationality to Haitian descendants.

Due to the lack of opportunities in the neighboring country, the Dominican Republic became one of the great recipients of Haitian nationals, who frequently formed families in the country. This context became even more salient after the natural catastrophes in Haiti (the large earthquake and tsunami in 2010), the flow of immigrants intensified considerably, which began to generate an anti-immigration sentiment in the Dominican state $^{56}$.

Several measures began to hinder access to Dominican nationality by Haitian descendants, which became a public problem with the growth of people with no state $^{57}$. It could be said that there is a deliberately denationalization policy by the Dominican State ${ }^{58}$. In 2011, the Inter-American Court ruled on the issue, which was followed by several negative reactions by domestic actors that culminated with the end of cooperation between the country's government and the Inter-Ame-

\footnotetext{
56 Available at: https://www.migrationpolicy.org/article/haiti-painful-evolution-promised-land-migrant-sending-nation, 01 Feb., 2021. 57 Available at: https://www.hrw.org/news/2016/11/29/haitistateless-people-trapped-poverty, acesso em: Jan. 20, 2021.

58 This policy was reinforced by the Dominican Constitutional Court in the 168/13 sentence. For more, see RIBEIRO, Daniela Menengoti Gonçalves; SILVA, Rodrigo Ichikawa Claro. A desnacionalização e as violações de direitos humanos na República Dominicana. Revista de Direito Internacional, v. 14, n. 2, p. 331-248, 2017.
} 
rican Court. In this particular situation, the country's Supreme Court was a key actor. In 2014, it ruled against accepting the jurisdiction of the Inter-American Court. It declared Executive Branch's instrument of ratification as unconstitutional for not having followed the domestic processes, which required voting in the Legislative. Thus, in practice, the Dominican Supreme Court "put the country on the path to partially exiting the American Convention." 59 . The Inter-American Court continues receiving cases, but the Dominican government no longer appears before the Court.

That the Court's decision generated several internal disputes regarding its binding force was revealed to be a theme of great political importance and, at times, due to polarization, was reinforced by reactions contrary to the decision of the country's Supreme Court, where those who criticized the decision of the main domestic court were openly attacked, accused of being traitors ${ }^{60}$. Thus, the decision by the Inter-American Court can be categorized in the group of "socially divisive themes". Moreover, issues of citizenship also tangentially touch on other categories, especially "national identity".

\subsection{European Court of Human Rights}

The second regional system of human rights protection analyzed here is the European system. The European Court is the oldest regional court with specific jurisdiction on human rights matters. As Table 2 shows, in at least three the threat strategy of withdrawing was undeniably used. As will be shown later on, all cases were situations in which judicialization of mega-politics can be identified as a present condition.

Greece was the only member-State in the European system that actually stopped being part of the European Court after formal withdrawal. It happened during the Greek authoritarian regime, when Denmark, Norway, Sweden, and the Netherlands filed a joint complaint against the military coup in the country, which ended with a decision contrary to the Greek government. The actions of colonels, seizing power, was classified as a violation of the Convention. The request to withdraw

\footnotetext{
59 CONTESSE, Jorge. "Resisting the Inter-American Human Rights System”. Yale J. Int'l L., v. 44, n. 2, p. 180-232, 2019.

${ }_{60}$ The report by the Inter-American Commission on Human Rights highlights that situation. Available at: https://www.oas.org/ en/iachr/media_center/preleases/2013/097a.asp, acesso em: Feb. 4, 2021.
}

was made in 1969 by the military junta. Greece returned in $1976^{61}$. It is an undeniable case of mega-politics, more precisely, the questioning of the legitimacy itself of the Greek political regime, established by the military coup.

The other two cases were mere threats. In the case of the United Kingdom, two themes dealt with in rulings by the European Court are clear cases of mega-politics: one on the issue of inmates' voting rights and another involving rulings on practices related to British participation in actions arising from the war on terror - with the spotlight on one issue involving deportation of Islamic radicals ${ }^{62}$. Regarding mega-politics categorization, the first deals directly with issues classified as political-electoral processes - and possibly fits into socially divisive themes. The second decision group deals with cases connected to national security and foreign policy issues, topics categorized by $\mathrm{Hirsch}^{63}$, as mentioned, as prerogative of the Executive ${ }^{64}$.

Another country that threatened to withdraw from the European Court was Russia. The Russian contestation is probably the most flagrant resistance faced by the ECHR in the last decades ${ }^{65}$. As a result of the sig-

${ }_{61}$ MADSEN, Mikael Rask. Resistance to the European Court of Human Rights: The Institutional and Sociological Consequences of Principled Resistance. In: BREUER, M. (ed.) 'Principled Resistance' to ECtHR Judgments - A New Paradigm?. Springer, 2019. p. 35-52,.

${ }^{62}$ MADSEN, Mikael Rask. From Boom to Backlash? The European Court of Human Rights and the Transformation of Europe. In: AUST, H.; ESRA, D. (ed.). The European Court of Human Rights: Current Challenges in Historical and Comparative Perspective. Edward Elgar Publishing, 2021; VOETEN, Erik. Populism and Backlashes against International Courts. Perspectives on Politics, p. 01-16, 2019.

${ }_{63}$ HIRSCHL, Ran. The Judicialization of Mega-Politics and the Rise of Political Courts. Annual Review of Political Science, v. 11, p. 93-118, 2008.

${ }^{64}$ The United Kingdom's resistance to the Court was translated into the first large initiative promoted by a member-State to contain the advancement of the European Court. It became known as the Brighton Declaration of 2012. An initiative that, under the guise of defending parliamentary supremacy, attempted to restrict the reach of the European Court of Human Rights. Despite being an action led by the United Kingdom, the initiative was supported by other countries that had the same critique on the Court's rulings, notably Belgium, Switzerland, the Netherlands and, mainly, Denmark. The latter also sponsored its own initiative later on, named the Copenhagen Declaration. For more, see: MADSEN, Mikael Rask. From Boom to Backlash? The European Court of Human Rights and the Transformation of Europe. In: AUST, H.; ESRA, D. (ed.). The European Court of Human Rights: Current Challenges in Historical and Comparative Perspective. Edward Elgar Publishing, 2021.

${ }^{65}$ SOLEY, Ximena; STEININGER, Silvia.Parting ways or lashing back? Withdrawals, backlash and the Inter-American Court of $\mathrm{Hu}-$ man Right. International Journal of Law in Context, v. 14, n. 2, p. $237-$ 
nificance of its attacks against the Court, human rights activists frequently comment on a possible "Ruxit" ${ }^{66}$. In the Russian case, some rulings also touched upon issues of mega-politics in the Court, being often associated by analysts as the source of critiques by the State towards the European Court. One highlight is the case of votes for inmates ${ }^{67}$. The hostility against the European Court was strengthened after two more recently conflicts involving Georgia and Ukraine (Crimea), with a large number of complaints arising from these conflicts as well as an inter-state one. Due to several divergences between the Russian government and the European Court, the country's parliament (Duma) and Constitutional Court created a new rule defining that to be followed, orders from Strasburg needed to be in accordance with the country's legislation, inverting the system's own rationale. In practice, this means that Russia chooses when to follow the Court's decisions (Madsen, 2021). It is worth mentioning that this action was not a withdrawal, but a domestic reform that substantially harms the relations between the Court and the Russian State.

The literature still highlights other cases in which political leaders threatened to withdraw, such as Denmark and France ${ }^{68}$. However, considering that these were not threats made by members of the government, we opted to exclude those cases.

\subsection{African Court on Human and Peoples' Rights}

The African Court on Human and Peoples' Rights is the most recent international court. It has a hybrid system, which allows States to grant access to citizens and NGOs to the African Court on Human and Peoples' Rights indirectly via the African Commission - similarly to the Inter-American system and the European one until the late 1990s -, as well as directly, similarly to how the European system works now. Thus, to accept the Court's jurisdiction, it is required to adhere to a spe-

\footnotetext{
257, 2018.

${ }_{66}$ Available at: https://www.politico.eu/article/ruxit-russian-human-rights/, acesso em: Jul. 9, 2020.

${ }^{67}$ MADSEN, Mikael Rask; CEUBLAK, Pola; WEIBUSCH, Micha. Backlash against International Courts: Explaining Resistance to International Courts. International Journal of Law in Context, v. 14, n. SI2, p. 197-220, 2018.

68 MADSEN, Mikael Rask. Resistance to the European Court of Human Rights: The Institutional and Sociological Consequences of Principled Resistance. In: BREUER, M. (ed.) 'Principled Resistance' to ECtHR Judgments - A New Paradigm?. Springer, p. 35-52, 2019.
}

cific protocol related to the African Charter on Human and Peoples' Rights, referred to as the Court's Protocol. However, to accept direct access by individuals and NGOs it is also necessary to adhere to a specific declaration, placed on article 34(6) of the same protocol ${ }^{69}$. Of the 55 States belonging to the African Union, 31 accepted the Court's Protocol, however only 10 accepted the special clause that grants direct access to individuals and NGOs. Of these 10, four have withdrawn from it ${ }^{70}$. This behavior was classified here as a partial withdrawal, considering that States do not usually file against their peers in human rights proceedings in international courts.

Rwanda was the first country to translate its dissatisfaction via an effective measure. The State removed the possibility from individuals and NGOs to access the organ seeking reparation, by denouncing the protocol's declaration ${ }^{71}$. The matter that motivated the withdrawal was a ruling involving the conviction of an opposition leader to 15 years of prison in the country, after being accused of several crimes such as terrorism, incentive to genocide, and attack on State authority. The African Court understood the ruling as a case against freedom of expression by the plaintiff. It was understood that, despite the Rwandan law that forbids making light of genocide being unquestionably legal, the measures taken by the state were disproportional ${ }^{72}$. The repeal of the declaration that granted access to individuals and NGOs to petition against the country in the Court was justified based on this case. Rwanda argued in its request to withdraw direct access that its exit became the alternative to be followed after "a fugitive from - the Tutsi genocide - justice [who] has, pursuant to the above-mentioned Declaration, secured the right to be heard

69 Article 34(6) of PROTOCOL TO THE AFRICAN CHARTER ON HUMAN AND PEOPLES' RIGHTS ON THE ESTABLISHMENTOF AN AFRICAN COURT ON HUMAN AND PEOPLES' RIGHTS, Available at: https://pt.african-court.org/images/Basic $\% 20$ Documents/africancourt-humanrights.pdf. acesso em: Feb. 9, 2021. For more details (in Portuguese) regarding the individual access to the African Court see NASCIMENTO, Marília Aguiar Ribeiro. $\mathrm{O}$ acesso do indivíduo às instâncias de proteção do Sistema Africano de Proteção dos Direitos do Homem e dos Povos. Revista de Direito Internacional, v. 9, n. 1, p.103-124, 2012.

${ }^{70}$ Data available in the Court's website: https://www.african-court. org/wpafc/welcome-to-the-african-court/

${ }^{71}$ VOETEN, Erik. Populism and Backlashes against International Courts. Perspectives on Politics, p. 01-16, 2019.

72 DALY, T.; WIEBUSCH, M. The African Court on Human and Peoples' Rights: Mapping resistance against a young court. International Journal of Law in Context, v. 14, n. 2, p. 294-313, 2018. 
by the Honourable Court, ultimately gaining a platform for reinvention" ${ }^{\text {"73. }}$.

There is no doubt that the mentioned ruling was a matter of the highest political relevance to the country. In this case, there is a clear "socially divisive theme", especially due to the nature of genocide itself, which placed ethnic national groups as enemies. Considering the remaining situations discussed by Hirschl ${ }^{74}$ as signs of mega-politics, the ruling equally touches on issues of "national identity" as well as "national reconstruction". This is evident given the position of the country's minister justice on the Court's decision, in which he stated that the court became a stage for "convicted genocide fugitives" 75 .

Following Rwanda, Tanzania was the second State to denounce art. 34(6) of the protocol, in 2019. By declaring its intention to withdraw from the declaration, the Ministry of Foreign Affairs in the country did not provide detailed explanations on the motivations for it. In a first analysis, the case of Tanzania seems to have been motivated less by a qualitative attribute of a specific ruling and more by the quantity of measures taken against the State. The country is the one that has most cases in the African court - $43 \%$ of all finalized cases in the $\mathrm{ACHPR}^{76}$ and $63 \%$ of the total cases awaiting trial. On this issue, one researcher stated that the initial diagnosis would be that "Tanzania had reached litigation fatigue" $" 77$. Nonetheless, the same academic highlighted a qualitative importance: [a]lthough neither the notice of withdrawal nor an official statement mentioned it, there is reason to believe that the Court's ruling on sensitive issues of socio-political relevance in Tanzania may have contributed significantly to the withdrawal"78.

\footnotetext{
73 ADJOLOHOUN, Segnonna. A crisis of design and judicial practice? Curbing state disengagement from the African Court on $\mathrm{Hu}-$ man and Peoples' Rights, African Human Rights Law Journal, v. 20, n. 1, p. 1-40, 2020.

${ }^{74}$ HIRSCHL, Ran. The Judicialization of Mega-Politics and the Rise of Political Courts. Annual Review of Political Science, v. 11, p. 93-118, 2008.

75 Available at: http://opiniojuris.org/2020/05/19/a-court-incrisis-african-states-increasing-resistance-to-africas-human-rightscourt/. Acesso em: Nov. 1, 2020.

76 Available at: https://www.ejiltalk.org/individual-and-ngo-accessto-the-african-court-on-human-and-peoples-rights-the-latest-blowfrom-tanzania/. Acesso em Nov. 1, 2020.

${ }^{77}$ ADJOLOHOUN, Segnonna. A crisis of design and judicial practice? Curbing state disengagement from the African Court on $\mathrm{Hu}-$ man and Peoples' Rights. African Human Rights Law Journal, v. 20, n. 1, p. 1-40, 2020.

${ }_{78}$ ADJOLOHOUN, Segnonna. A crisis of design and judicial prac-
}

Therefore, some important cases on issues of mega-politics were identified. Sensitive cases such as the one that demanded that a country amend its constitution, so that the registration of independent candidates from political parties were possible, which in our classification regarded political-electoral processes, to the case in which the death penalty in the country's penal code was considered a violation to the right to life and thus required a modification of the code and its removal, topic categorized in the group of socially divisive themes.

The timing of the last case ruled by the court before denouncing the declaration, relative to the result of elections $^{79}$, may be a good example to help identify the effect of decisions on sensitive issues in the withdrawal of Tanzania. The process involving the aforementioned case began in 2018 and was finalized in July 2020, right after the country's withdrawal. The case of Tanzania becomes paradigmatic when it comes to the challenge of the ACHPR maintaining operations, given that it houses the institution's headquarters.

The partial withdrawals of Rwanda and Tanzania were followed by Benin and the Ivory Coast - both in 2020. The former, in its withdrawal declaration, accused the court of interfering in matters of State sovereignty, but also did not justify the action based on a specific case. However, some situations awakened harsher critiques to the Court. The first situation was on ruling regarding the suspension of the decision on the garnishment of assets from a citizen to pay a large sum of money to the State. In addition, a set of decisions involving demands from opposition politicians were also targets of substantial critiques. More than half of the cases received were regarding questionings of opposition politicians, including issues related to the 2020 elections and the presidential election of 2021 of an exiled politician, who got from the Court a provision to suspend municipal elections ${ }^{80}$. The first case may not fit in mega-politics categories. However, decisions on elections are clearly within the category of political-electoral processes.

tice? Curbing state disengagement from the African Court on $\mathrm{Hu}-$ man and Peoples' Rights. African Human Rights Law Journal, v. 20, n. 1, p. 1-40, 2020.

${ }^{79}$ Available at: https://www.african-court.org/en/index.php/56-pending-cases-details/1185-app-no-018-2018-jebra-kambole-v-the-unitedrepublic-of-tanzania-details, 01, Nov., 2020.

${ }^{80}$ Available at: http://opiniojuris.org/2020/05/19/a-court-incrisis-african-states-increasing-resistance-to-africas-human-rightscourt/. Acesso em: Nov. 2, 2020. 
On the decision to denounce art. 34 (6) and the African Court's rulings on electoral processes, the communications minister stated "[i]t stands beyond the jurisdiction of the African Court to order a state to suspend its electoral process, which is an act of sovereignty" ${ }^{\prime \prime 1}$. Adjolohoun argues that "Benin's withdrawal can reasonably be seen as a preventive shield against a too intrusive Court that may as well, for instance, go as far as threatening the incumbent President's bid for a second term by reversing the outcome of the March 2021 presidential election should the case arise" ${ }^{\prime 2}$.

With regards to Ivory Coast, there was also no evident association between the partial withdrawal and its withdrawal justifications - the denounce statement restricted itself to vague mentions that the rulings by the ACHPR threatened state sovereignty an internal stability. Nevertheless, the timing of the withdrawal coincided with the submission of a case made by an opposition political party. As a result of the action, there was a provision imposed by the African Court against the aforementioned State, requesting the suspension of the imprisonment and subsequent freedom with bail of the country's former prime-minister (who opposes the current government), as well as other 19 political prisoners. According to the Court, the arrest warrant violated due process and had as main goal to keep the former prime-minister from participating in the upcoming elections. This is indeed seen as the immediate cause for the withdrawal of the Ivory Coast, as the Court decided against the execution of an international arrest warrant ${ }^{83}$. Following the demand made by the African Court, the government of the Ivory Coast presented its request for partial withdrawal.

In conclusion, similarly to the cases described in the other regional systems, the four partial withdrawals of States from the African Court show that, to some extent, decisions on issues of mega-politics are necessary ingredients for there to be a withdrawal (or threat of

\footnotetext{
${ }^{81}$ ADJOLOHOUN, Segnonna. A crisis of design and judicial practice? Curbing state disengagement from the African Court on $\mathrm{Hu}-$ man and Peoples' Rights. African Human Rights Law Journal, v. 20, n. 1, p. 1-40, 2020.

${ }_{82}$ ADJOLOHOUN, Segnonna. A crisis of design and judicial practice? Curbing state disengagement from the African Court on $\mathrm{Hu}-$ man and Peoples' Rights. African Human Rights Law Journal, v. 20, n. 1, p. 1-40, 2020.

${ }_{83}$ ADJOLOHOUN, Segnonna. A crisis of design and judicial practice? Curbing state disengagement from the African Court on $\mathrm{Hu}-$ man and Peoples' Rights. African Human Rights Law Journal, v. 20, n. 1, p. $1-40,2020$
}

one) by a State in a RHRC. Specially since 2017, the African system not only increased the number of rulings, but also had a significant increase in decisions on politically sensitive topics ${ }^{84}$. In particular, there is the additional issue in the African system, that all states that withdrew had, to some degree, a case in the Court involving electoral processes or other matters associated to political disputes. And it is no surprise that this particular type of mega-politics arouses uncompromising attitudes by governments, considering that, as Hirschl states, "the most overtly political area is the judicialization of the democratic process itself" $"$.

\section{Mega-politics as a necessary condition and possible combinations for sufficiency}

After researching the cases, it is then necessary to evaluate if the judicialization of mega-politics really is a necessary condition. To do so, a simple analysis was used, based on set-theory techniques - in particular, Qualitative Comparative Analysis (QCA) studies ${ }^{86}$. With this approach, for a condition to be necessary, it needs to be a superset of the specific result evaluated. That is, all the cases that present the outcome analyzed ${ }^{87}$ must have the necessary condition ${ }^{88}$, regardless if other cases that do not present the outcome also have that same necessary condition present ${ }^{8990}$ - this situation is gra-

${ }^{84}$ DALY, T.; WIEBUSCH, M. The African Court on Human and Peoples' Rights: Mapping resistance against a young court. International Journal of Law in Context, v. 14, n. 2, p. 294-313, 2018.

${ }^{85}$ HIRSCHL, Ran. The Judicialization of Mega-Politics and the Rise of Political Courts. Annual Review of Political Science, v. 11, p. 93-118, 2008.

${ }^{86}$ QCA is it methodology emergent from studies in Political Science and International Relations for comparative research. This work did not intend to conduct a QCA study, only to extract some methodological reflections that are used by this approach.

${ }^{87}$ In the case of this paper, withdrawals or threats to withdraw from RHRCs.July

${ }^{88}$ A qual neste estudo corresponde a decisões sobre assuntos considerados de mega-política.

${ }^{89}$ GEORGE, Alexander; BENNETT, Andrew. Case Studies and Theory Development in the Social Science. Cambridge, Massachusetts: MIT Press, 2005.

90 Thus, for example, there may be cases in which there are rulings on mega-politics in regional human rights courts in which the country object of this ruling did not withdraw (partially or formally) nor did it threaten to leave the respective court. That hypothesis does not invalidate the argument of a necessary condition. It would only be invalidated if there were cases containing the result (withdrawals 
phically represented in Figure 1. Consequently, result Y (withdrawals or threat to withdraw) implies the existence of condition $\mathrm{X}$ (rulings on issues of mega-politics). In other words: $\mathrm{X} \leftarrow \mathrm{Y}$ (if $\mathrm{Y}$, then $\mathrm{X}$ ). Nevertheless, there may be a case that is covered by $\mathrm{X}$ that did not result in withdrawals or threats ${ }^{91}$.

\section{Figure 1}

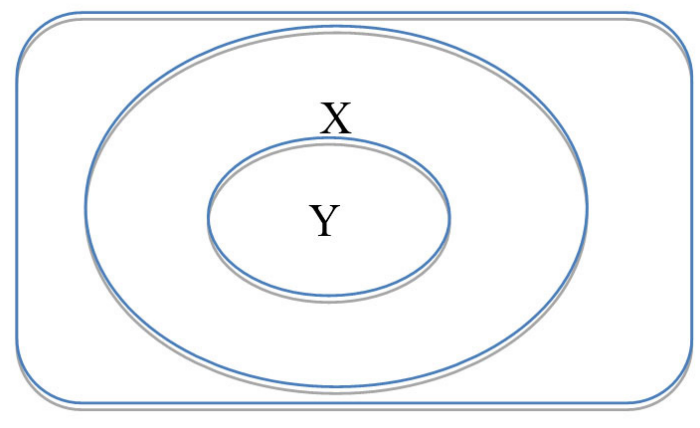

Source: the authors.

Schneider and Wagemann ${ }^{92}$ indicate that a basic element for a condition to be necessary is that it possesses a consistency of at least 0.9 in the total of cases analyzed. In other words, there is a tolerance that indicates that not all cases that contain the outcome $(\mathrm{Y})$ must have the condition $(\mathrm{X})$ for it to be considered necessary. The consistency of a necessary condition may be reached by dividing the values where the condition is present for the total of cases. In the categorization done in this paper, all 11 cases researched thus far point to the judicialization of issues considered of mega-politics, which gives a fully satisfied necessary consistency ${ }^{93}$.

Among the mega-politics categories, three were the more frequent in the cases: a) political-electoral processes, b) measures critical to the regime, c) socially divisive themes. Thus, the ruling of issues framed within one of these categories may have a pernicious effect for the institution - when combined with other conditions. Since this is a preliminary analysis, it is still necessary to

or threats) in which the necessary condition evaluated here was not present.

${ }_{91}$ In Figure 1, it would be the whole space covered by X, excluding Y.

${ }^{2}$ SCHNEIDER, Carsten; WAGEMANN, Claudius. Set-Theoretic Methods for the Social Sciences: A Guide to Qualitative Comparative Analysis (Strategies for Social Inquiry). Cambridge: Cambridge University Press, 2012.

${ }^{3}$ As an example, even if one of the cases were reclassified later and categorized as a situation where there were no rulings on issues of mega-politics, there would be a consistency of 0.91 , satisfying the criterium. further understand the cases to determine the existence of judicialization of mega-politics. In some situations, there is a certain margin to assume that judicialized issues are effectively mega-politics issues ${ }^{94}$.

It is important to remember that the necessary condition is a factor that enables the result, but often it is not the determining element ${ }^{95}$. This paper does not intend discuss in detail the configurations considered sufficient for the results. As clearly explained in the introduction, the concern is only with necessity. Nevertheless, a brief reflection may point to some hypotheses that bring about possible conditions that, along with the judicialization of mega-politics, may reveal paths sufficient for the result.

A priori, two conditions may be seen in combination with judicialization of mega-politics in future studies. One of them is more common in comparative politics analysis, which is the level of democracy in the States. The other has recently been gaining more traction in ideational analysis within Political Science and International law: populism ${ }^{96}$.

Just as a preliminary evaluation, we identified the democracy indexes of the States at the moment of a total or partial withdrawal (or threats), as well as level of populism of its leader. The data on democracy were taken from the liberal democracy indicator V-Dem ${ }^{97}$; the one on populism from the Global Populism ${ }^{98}$ database. They are presented in the following table.

94 As hard cases in the process of categorization, perhaps Trinidad
and Tobago and the Dominican Republic can be cited.
95 For the condition of judicialization of mega-politics to be con-
sidered a determining element, that on its own is sufficient to ex-
plain withdrawals or threats, it must not only be necessary but also
sufficient. SCHNEIDER, Carsten; WAGEMANN, Claudius. Set-
Theoretic Methods for the Social Sciences: A Guide to Qualitative Compar-
ative Analysis (Strategies for Social Inquiry). Cambridge: Cambridge
University Press, 2012.
96 To contextualize the reader with more recent literature in political
science, see: MUDDE, Cas. The populist zeitgeist. Government and
Opposition, v. 39, n. 4, p. 541-563, 2004; MUDDE, Cas; KALTWAS-
SER, Cristóbal Rovira. Populism: a very short introduction. Oxford:
Oxford University Press, 2017; NORRIS, Pippa; INGLEHART,
Ronald. Cultural Backlash: Trump, Brexit, and Authoritarian Pop-
ulism. New York: Cambridge University Press, 2019. Additionally,
this journal has published an important issue dealing with the impact
of populism with regards to International Law. See the editorial:
MOROSINI, Fabio Costa; LIXINSKI, Lucas Editorial: Populism
and International Law: Global South Perspectives. Revista de Direito
Internacional, v 17, n. 2, p. 56-60, 2020.
97 Available at: https://www.v-dem.net/en/. Acesso em: Feb 6,
2021.
98 Available at: https://populism.byu.edu/Pages/Data. Acesso em: 
Table 3: Other variables

\begin{tabular}{|c|c|c|c|c|c|}
\hline $\begin{array}{l}\text { Count- } \\
\text { ry }\end{array}$ & Year & $\begin{array}{l}\text { Demo- } \\
\text { cracy } \\
\text { level* }\end{array}$ & $\begin{array}{l}\text { Degree } \\
\text { of po- } \\
\text { pulism }\end{array}$ & $\begin{array}{l}\text { Result } \\
\text { of th- } \\
\text { reat }\end{array}$ & $\begin{array}{l}\text { Pre- } \\
\text { sençce } \\
\text { of ru- } \\
\text { ling on } \\
\text { mega- } \\
\text { politics }\end{array}$ \\
\hline Benin & 2020 & $\begin{array}{l}\text { Electo- } \\
\text { ral au- } \\
\text { tocracy } \\
(0.46)\end{array}$ & & $\begin{array}{l}\text { Partial } \\
\text { Withdra- } \\
\text { wal }\end{array}$ & Yes \\
\hline $\begin{array}{l}\text { Ivory } \\
\text { Coast }\end{array}$ & 2020 & $\begin{array}{l}\text { Electo- } \\
\text { ral au- } \\
\text { tocracy } \\
(0.38)\end{array}$ & & $\begin{array}{l}\text { Partial } \\
\text { Withdra- } \\
\text { wal }\end{array}$ & Yes \\
\hline Rwanda & 2016 & $\begin{array}{l}\text { Electo- } \\
\text { ral au- } \\
\text { tocracy } \\
(0.15)\end{array}$ & & $\begin{array}{l}\text { Partial } \\
\text { Withdra- } \\
\text { wal }\end{array}$ & Yes \\
\hline $\begin{array}{l}\text { Tanza- } \\
\text { nia }\end{array}$ & 2019 & $\begin{array}{l}\text { Electo- } \\
\text { ral au- } \\
\text { tocracy } \\
(0.34)\end{array}$ & & $\begin{array}{l}\text { Partial } \\
\text { Withdra- } \\
\text { wal }\end{array}$ & Yes \\
\hline Greece & 1969 & $\begin{array}{l}\text { Closed } \\
\text { autocra- } \\
\text { cy }(0.06)\end{array}$ & & $\begin{array}{l}\text { Formal } \\
\text { Withdra- } \\
\text { wal }\end{array}$ & Yes \\
\hline $\begin{array}{l}\text { United } \\
\text { King- } \\
\text { dom }\end{array}$ & 2011 & $\begin{array}{l}\text { Liberal } \\
\text { demo- } \\
\text { cracy } \\
(0.81) \\
\end{array}$ & $\begin{array}{l}\text { Not } \\
\text { populist }\end{array}$ & $\begin{array}{l}\text { Do- } \\
\text { mestic } \\
\text { Reform }\end{array}$ & Yes \\
\hline Russia & 2015 & $\begin{array}{l}\text { Electo- } \\
\text { ral au- } \\
\text { tocracy } \\
(0.13) \\
\end{array}$ & $\begin{array}{l}\text { So- } \\
\text { mewhat } \\
\text { populist }\end{array}$ & $\begin{array}{l}\text { Do- } \\
\text { mestic } \\
\text { Reform }\end{array}$ & Yes \\
\hline Peru & 1999 & $\begin{array}{l}\text { Electo- } \\
\text { ral au- } \\
\text { tocracy } \\
(0,16)\end{array}$ & & $\begin{array}{l}\text { Formal } \\
\text { Withdra- } \\
\text { wal }\end{array}$ & Yes \\
\hline $\begin{array}{l}\text { Domi- } \\
\text { nican } \\
\text { Republic }\end{array}$ & 2011 & $\begin{array}{l}\text { Electo- } \\
\text { ral au- } \\
\text { tocracy } \\
(0.34)\end{array}$ & $\begin{array}{l}\text { Not } \\
\text { populist }\end{array}$ & $\begin{array}{l}\text { Do- } \\
\text { mestic } \\
\text { Reform }\end{array}$ & Yes \\
\hline $\begin{array}{l}\text { Trinidad } \\
\text { and } \\
\text { Tobago }\end{array}$ & 1998 & $\begin{array}{l}\text { Electo- } \\
\text { ral de- } \\
\text { mocracy } \\
(0.66)\end{array}$ & & $\begin{array}{l}\text { Formal } \\
\text { Withdra- } \\
\text { wal }\end{array}$ & Yes \\
\hline $\begin{array}{l}\text { Vene- } \\
\text { zuela }\end{array}$ & 2011 & $\begin{array}{l}\text { Closed } \\
\text { autocra- } \\
\text { cy }(0.16)\end{array}$ & $\begin{array}{l}\text { Very } \\
\text { populist }\end{array}$ & $\begin{array}{l}\text { Formal } \\
\text { Withdra- } \\
\text { wal }\end{array}$ & Yes \\
\hline
\end{tabular}

Source: the authors from Global Populism database and V-DEM “Liberal Democracy” codebook v.5.

Unfortunately, not all data are available in the database on populism. The Global Populism database restricts itself to evaluating the speeches of presidents and prime-ministers of only 40 countries (2000-2019)

Feb 6, 2021 leaving out the large majority of cases researched here. In any case, there are more recent works that have considered the presence of a populist government as a condition that can stimulate the resistance of states to International Courts ${ }^{99}$. Considering Table 3, Venezuela may serve as a typical case for future evaluations, more in-depth studies on the combination of mega-politics judicialization where the populist regime and withdrawal of a member-State from a RHRC. This may also have implications for future cases that rule on mega-politics issues in countries that have recently become ruled by populist leaders ${ }^{100}$.

More significant seem to be the configurations that combine the level of democracy and judicialization of mega-politics. At a first glance, it is noticeable that, with the exception of Trinidad and Tobago and the United Kingdom, all remaining cases were involved in autocratic regimes. It is worth remembering that the use of the "liberal democracy" indicator from V-Dem was not random but taking into account that one of the characteristics of liberal democratic regimes is precisely preserving the rights of minorities through institutions, including international ones ${ }^{101}$. The weakening of institutions such as regional human rights courts would in fact be a symptom of the weakening of a project of international liberal order ${ }^{102}$.

99 VOETEN, Erik. Populism and Backlashes against International Courts. Perspectives on Politics, p. 01-16, 2019.

100 for example, Brazil has been an object of action in politically sensitive issues. Some of them, of crucial importance for current president Jair Bolsonaro, such as the matter involving the Araguaia Guerilla in the Inter-American Court of Human Rights. Among other issues, the Bolsonaro government keeps in its support base several members of the Armed Forces. Having a populist government in Brazil has already been identified as a negative factor in certain aspects of international law, though not necessarily all. On this issue, see: TASQUETTO, Lucas; RORIZ, João. "Deus em Davos": o direito internacional entre reacionários e neoliberais no governo Bolsonaro. Revista de Direito Internacional, v. 17, n. 2, p. 120-137, 2020. 101 On the relationship between liberal democracy, institutions, and minorities, especially related to populism, see: MUDDE, Cas; KALTWASSER, Cristóbal Rovira. Populism: a very short introduction. Oxford: Oxford University Press, 2017; NORRIS, Pippa; INGLEHART, Ronald. Cultural Backlash: Trump, Brexit, and Authoritarian Populism. New York: Cambridge University Press, 2019. Sobre essas questões e as instituições judiciais internacionais, ver POSNER, Eric. Liberal Internationalism and the Populist Backlash. University of Chicago Public Law \& Legal Theory Paper Series, p. 795-819, 2017; VOETEN, Erik. Populism and Backlashes against International Courts. Perspectives on Politics, p. 01-16, 2019.

102 IKENBERRY, John. The end of the liberal order? International Affairs, v. 94, n. 1, p. 7-23, 2018. 
From this point, some hypotheses maybe suggested: 1) the combination between an autocratic regime and a ruling on mega-politics may be a sufficient trajectory to arrive at the withdrawal of a state from a regional human rights court; or perhaps: 2) the absence of a liberal democratic regime, combined with the presence of a ruling on a mega-politics issue, would correspond to a sufficient configuration for the result (withdrawal or threat to withdraw). Following this, analyses using comparative methods (such as Qualitative Comparative Analysis) may be a good alternative for future studies that seek to understand the possible role that these other conditions may play.

\section{Conclusion}

This article is part of a larger project, which seeks to analyze the challenges that international human rights institutions have been having in the context of contemporary politics. It is an effort in understanding how possible preferences and configurations of domestic policies can implicate in a backlash or pushbacks against those institutions, arising from the behavior of states. Specifically, we were interested in evaluating if the judicialization of mega-politics can be considered a necessary condition for the existence of a particular type of resistance (withdrawal or threat to withdraw by states) to a restrict group of international human rights institutions (regional courts).

In a preliminary comparative analysis, there is indication pointing towards the confirmation the hypothesis presented. The cases researched reveal situations of the judicialization of mega-politics and, at certain points, they were even suggested - whether by the literature or by statements from government representatives - as one of the crucial reasons behind the States' threat to withdraw or effective withdrawal.

Notwithstanding, the data found may need to be refined conceptually, aiming to lessen certain inconsistencies, as well as refining operationalization of theoretical elements. This study, in fact, was a first effort to operationalize the concept of the judicialization of mega-politics for content analysis. In addition, future works may evaluate the complementary hypotheses raised here, which could unravel further understandings regarding the specific phenomenon that can be called the de-judicialization of international human rights courts, incorporating in the analysis issues such as levels of democracy and the existence or not of a populist government.

Regardless, the results presented here bring new issues to be reflected upon, aiming to ensure the institutional health of regional international human rights courts. The withdrawals by States from these organs are frequently understood as factors that provoke backlash against the courts and may even threaten their existence itself. This could a symptom of a process of deglobalization from the part of international human rights institutions.

\section{References}

ABEBE, Daniel Y; GINSBURG, Tom. The Dejudicialization of International Politics? International Studies Quarterly, v. 63, n. 3, p. 521-530, 2019.

ABBOTT, Kenneth et al. "The concept of legalization". International Organization, v. 54, n. 3, p. 401-419, 2000.

ADJOLOHOUN, Segnonna. A crisis of design and judicial practice? Curbing state disengagement from the African Court on Human and Peoples' Rights. African Human Rights Law Journal, v. 20, n.1, p. 1-40, 2020.

ALTER, Karen J; HAFNER-BURTON, Emilie Marie; HELFER, Laurence. Theorizing the Judicialization of International Relations. International Studies Quarterly, v. 63, n. 3, p. 449-463, 2019.

BERNARDI, Bruno Boti. O sistema interamericano de direitos humanos e a justiça de transição no Peru. Revista de Sociologia e Política, v. 23, n. 54, p. 43-68, 2015.

CONTESSE, Jorge. "Resisting the Inter-American $\mathrm{Hu}-$ man Rights System”. Yale J. Int'l L., v. 44, n. 2, 180-232, 2019.

DALY, T.; WIEBUSCH, M. The African Court on Human and Peoples' Rights: Mapping resistance against a young court. International Journal of Law in Context, v. 14, n. 2, p. 294-313, 2018.

DONNELLY, Jack. The Social Construction of International Human Rights. In: DUNNE, Tim; WHEELER, Nicholas J., Human Rights in Global Politics. Cambridge: Cambridge University Press, 1999. 
FORSYTHE, David. Human Rights in International Relations. 2. ed. Cambridge: Cambridge University Press, 2006.

FUKUYAMA, Francis. O fim da História e o último homem. Rio de Janeiro: Rocco, 1992.

GLANVILLE, Luke. Sovereignty and the responsibility to protect: a new history. Chicago: The University of Chicago Press, 2014.

GEORGE, Alexander; BENNETT, Andrew. Case Studies and Theory Development in the Social Science. Cambridge, Massachusetts: MIT Press, 2005.

HILLEBRECHT, Courtney. Domestic Politics and International Human Rights Tribunals: the problem of compliance. Cambridge: Cambridge University Press, 2014.

HIRSCHL, Ran. The Judicialization of Mega-Politics and the Rise of Political Courts. Annual Review of Political Science, v. 11, p. 93-118, 2008.

HIRSCHL, Ran. The Judicialization of Politics. Oxford Handbook of Political Science. Oxford: Oxford University Press, 2011.

HIRSCHL, Ran. A Judicialização da Mega-Política e o surgimento dos Tribunais Políticos. Judicialização da Política, In: MOREIRA, Luis (org.) São Paulo: Editorial 22, 2012.

HURRELL, Andrew. On Global Order: power, values and constitution of international order. New York: Oxford, 2007.

IKENBERRY, John. Liberal internationalism 3.0: America and the dilemmas of liberal world order. Perspectives on Politics, v. 7, n. 1, p. 71-87, 2009.

IKENBERRY, John. The end of the liberal order? International Affairs, v. 94, n. 1, p. 7-23, 2018.

KRASNER, Stephen D. Structural causes and regime consequences: regimes as intervening variables. International Organization, v. 36, n. 2, p. 185-205, Spring, 1982.

MADSEN, Mikael Rask; CEUBLAK, Pola; WEIBUSCH, Micha. Backlash against International Courts: Explaining Resistance to International Courts. International Journal of Law in Context, v. 14, n. SI2, p. 197-220, 2018.

MADSEN, Mikael Rask. From Boom to Backlash? The European Court of Human Rights and the Transformation of Europe. In: AUST, H.; ESRA, D. (ed.). The
European Court of Human Rights: Current Challenges in Historical and Comparative Perspective. Edward Elgar Publishing, 2021.

MADSEN, Mikael Rask. Resistance to the European Court of Human Rights: The Institutional and Sociological Consequences of Principled Resistance. In: BREUER, M. (ed.) 'Principled Resistance' to ECtHR Judgments - A New Paradigm?. Springer, 2019. p. 35-52,

MORAVCSIK, Andrew. Taking Preferences Seriously: A liberal theory of international politics. International Organization, v. 51, n. 4, p. 513-553, 1997.

MORAVCSIK, Andrew. "The Origins of Human Rights Regimes: Democratic delegation in Postwar Europe". International Organization, v. 54, n.2, p. 217-252, 2020.

MUDDE, Cas; KALTWASSER, Cristóbal Rovira. Рориlism: a very short introduction. Oxford: Oxford University Press, 2017.

MUDDE, Cas. The populist zeitgeist. Government and Opposition, v. 39, n. 4, p. 541-563, 2004.

NORRIS, Pippa; INGLEHART, Ronald. Cultural Backlash: Trump, Brexit, and Authoritarian Populism. New York: Cambridge University Press, 2019.

POSNER, Eric. Liberal Internationalism and the Populist Backlash. University of Chicago Public Law \& Legal Theory Paper Series, p. 795-819, 2017.

RIBEIRO, Mikelli; RAMANZINI, Isabela; SANTOS, Alana. A Corte Interamericana De Direitos Humanos E a judicialização Internacional Da política doméstica. Meridiano 47 - Journal of Global Studies, v. 21, Jul. 2020.

SCHNEIDER, Carsten; WAGEMANN, Claudius. SetTheoretic Methods for the Social Sciences: A Guide to Qualitative Comparative Analysis (Strategies for Social Inquiry). Cambridge: Cambridge University Press, 2012.

SOLEY, Ximena; STEININGER, Silvia.Parting ways or lashing back? Withdrawals, backlash and the InterAmerican Court of Human Right. International Journal of Law in Context, v. 14, n. 2, p. 237-257, 2018.

TASQUETTO, Lucas; RORIZ, João. "Deus em Davos": o direito internacional entre reacionários e neoliberais no governo Bolsonaro. Revista de Direito Internacional, v. 17, n. 2, p. 120-137, 2020.

VOETEN, Erik. Populism and Backlashes against International Courts. Perspectives on Politics, p. 01-16, 2019. 
Para publicar na Revista de Direito Internacional, acesse o endereço eletrônico www.rdi.uniceub.br ou www.brazilianjournal.org.

Observe as normas de publicação, para facilitar e agilizar o trabalho de edição. 